\title{
CHELATION AND METAL-ION COMPLEX FORMATION OF CHITOSAN TREATED COTTON
}

\section{CHELATE DAN METAL-ION COMPLEKS DARI FORMASI CHITOSAN PADA PENCELUPAN KAIN}

\author{
Sudirman Habibie \\ Pusat Teknologi Industri Proses \\ Deputi Teknologi Industri Rancang Bangun dan Rekayasa \\ Badan Pengkajian dan Penerapan Teknologi \\ Gedung Teknologi 2 - TIRBR, Kawasan Puspiptek Serpong, \\ Tangerang 15314, Banten \\ Telp. (021)75875944 Ext. 318 \\ Email : sudirmanhabibie@yahoo.com
}

\begin{abstract}
Abstrak
Chitin dan chitosan adalah bahan "chelate" yang sangat kuat untuk ion transisi logam terutama tembaga, nikel dan merkuri, dan sifat-sifat ini yang akan intensif di bahas. Pada studi ini kain kapas (cotton) dikerjakan dengan larutan chitosan-asam polikarboksilat untuk memperoleh kain kapas-chitosan yang mengandung gugus group karboksilat $(-\mathrm{COOH})$ dan gugus amina $\left(-\mathrm{NH}_{2}\right)$ fungsional. Penggunaan asam polykarboksilat (asam sitrat dan maleik) pada pelarutan chitosan menghasilkan group karboksil 0,5 meqs/g pada kain yang dicelup dengan larutan chitosan asam karboksilat. Kemudian kain kapas yang telah mengandung gugus karboksilat dan gugus amina ini dicelupkan pada larutan garam logam (garam tembaga dan seng). Terbukti bahwa larutan garam tembaga (copper) memberikan warna biru pada kain, hal ini mengindikasikan telah terjadi reaksi kompleks atau "Chelate". Implikasi dari hasil ini maka diperkirakan kandungan group karboksil dan amina ini akan mempengaruhi pada pencelupan kain, namun hal ini tidak diuji.
\end{abstract}

Kata kunci : Chitosan, Kain Kapas, Chelate, asam asetat, asam citrate, asam maleik, tembaga sulphate, tembaga acetate.

\begin{abstract}
Chitin and chitosan are powerfull chelating agents for transition metal ions, particularly copper, nickel and mercury, and these properties have been extensively reviewed. In this study, cotton fabric has been treated with chitosanpolycarboxylic acid solution to form chitosan treated cotton fabric containing carboxyl $(-\mathrm{COOH})$ and amine $\left(-\mathrm{NH}_{2}\right)$ functional groups. The use of polycarboxylic acids (citric and maleic acids) to dissolve chitosan has given carboxyl groups 0.5 meqs/g into chitosan treated cotton fabrics. Instead, the complexing of the treated cotton samples with copper and zinc salts was examined. The copper salt solutions gave blue fabrics confirming easily that complexing or chelation had occurred. There are implications for dyeing cotton making use of these groups but this was not investigated.
\end{abstract}

Keyword : Chitosan, cotton fabric, chelation, acetic acid, citric acid, maleic acid, copper (II) sulphate, copper (II) acetate.

Diterima (received) : 20 Oktober 2014, Direvisi (reviewed) : 27 Oktober 2014, Disetujui (accepted) : 28 November 2014

\section{INTRODUCTION}

Chitosan has a demonstrated ability to bind transition metals and uranium while essentially ignoring group I and II metals, its metal-binding properties have attracted attention as a potential hazardous waste recovery material. ${ }^{1,2,3)}$ This metal-binding property has led to consideration of chitosan as low-cost material for use in, for example, waste water treatment plants, water containing radioactive elements, and streams contaminated by the accumulation of toxic 
metals released by industrial activities. ${ }^{4,5,6,7)}$ Compared with chitin, chitosan has higher sorption of lead. ${ }^{8)}$ and the maximum adsorption capacity of $\mathrm{Cu}(\mathrm{II})$ was found within each optimal $\mathrm{pH}$ range. ${ }^{9)}$ Laksono et $\mathrm{al}^{10)}$ found that the interaction chitosan with metal ions is indicated complex $\mathrm{s}$, but the interaction of chitosan to copper (II) is prefer a monolayer formation.

Several new chitosan derivatives have been used in hazardous waste recovery as toxic metal-binding agents in aueous environments. ${ }^{5}$ Four of new compounds, the products of the reaction of chitosan with mercaptosuccinic acid, thiirane, pyridoxal hydrochloride and succinamide, show promising results as binding agents for the above metal ions. The compound with mercaptosuccinic acid bound twice as much $\mathrm{Cd}^{2+}$, five times as much as $\mathrm{Pb}^{2+}$, and virtually no $\mathrm{Fe}^{2+}$ when compared to chitosan. The compound with thiirane bound three times as much as $\mathrm{Pb}^{2+}$, whereas the pyridoxal hydrochloride derivative bound $30 \%$ more $\mathrm{Cu}^{2+}$ and twice the $\mathrm{Pb}^{2+}$. The succinamide derivative gave results comparable to chitosan, but with decreased solubility at low $\mathrm{pH}$. Jiang et $\mathrm{al}^{11)}$ observed the removal of copper and nickel by the addition of the biodegradable chelating agent, chitosan and ethylenediamine tetraacetic acid (EDTA). They found the extraction ability for copper and nickel from the contaminated soil decreased as follows: chitosan $>$ EDTA $>$ sodium citrate, and the $\mathrm{pH}$ value of the eluents is the key to control the extraction, especially to chitosan solution.

The coordination numbers in chitosanmetal ion complexes appear to vary from metal to metal, but in the case of $\mathrm{Cu}^{2+}$, it is known that the nitrogen of the amine group at $\mathrm{C}-2$ is involved in binding and perhaps the hydroxyl group on C-3 or C-6 as well. ${ }^{12,13)}$ The rate of uptake of a number of transition metal ions by an excess of chitosan has been reported by Muzzarelli and Tubertini. ${ }^{14)}$ The equilibrium was reached in all cases after $45 \mathrm{~h}$ contact time, or after $30 \mathrm{~h}$ with a number of the metal ions. Koshijima et $\mathrm{al}^{15)}$ found that equilibrium was reached in the chitosan- $\mathrm{Cu}$ (II) system after $50 \mathrm{~h}$ at $30^{\circ} \mathrm{C}$. Hussein et a ${ }^{16)}$ found that the metal ions which strongly complexed to the amino groups of chitosan like Fe showed a smooth surface product, amorphous phase, thermally more stable and high electrical conductivity that other complexes.

To form a chelate, the involvement of $\mathrm{OH}$ or $-\mathrm{O}^{-}$groups on the $\mathrm{D}$-glucosamine residues as ligands andlor two or more $-\mathrm{NH}_{2}$ groups form one chain binding to the same metal ion is required ${ }^{17)}$, so the $-\mathrm{NH}_{2}$ groups could come from two chain segments of the same chain running in opposite direction, ${ }^{17)}$ as shown in Figure 1.

$$
\text { It has been reported that }
$$
carboxymethyl(CM)-chitin chelates the calcium ion specifically and that the chelate compound (CM-chitin - $\mathrm{Ca}^{2+}$ complex) adsorbs compounds containing hydrophobic aromatic rings, especially the benzyl group. ${ }^{18)}$ The chelating properties of chitosan can be enhanced. ${ }^{19)}$ Several N-benzylidene chitosans have been described, ${ }^{20)}$ among which the $\mathrm{N}$-salicylidene derivative ${ }^{21)}$ had increased chelating capacity for $\mathrm{Cu}(\mathrm{II})$. According to Hovey et $\mathrm{al}^{22)}$ derivatives from amines and 1-3-dicarbonyl compounds are good metal chelating agents.

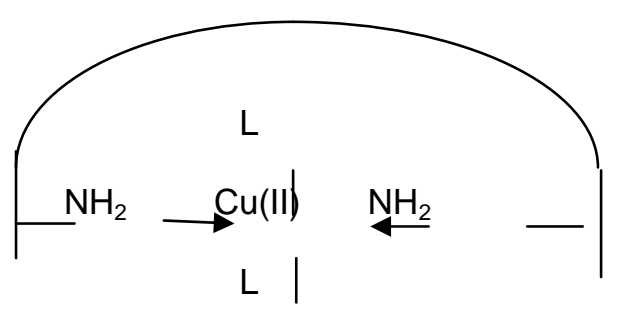

Figure 1.

Chelation structure

Chitin and chitosan are powerfull chelating agents for transition metal ions, particularly copper, nickel and mercury, and these properties have been extensively reviewed. ${ }^{23}$ Blair and $\mathrm{Ho}^{24)}$ reported that for fully deacetylated chitosan, all the free amine groups chelate to copper ions, and the maximum adsorption was consistent with a 2 : 1 glucosamine : copper complex. The interaction of chitin and chitosan with lead and chromium has been investigated. ${ }^{25)}$ The uptake of $\mathrm{Pb}$ (II) on chitin was approximately $21 \%$ of that on chitosan. The number of $N$ atoms in chitin and chitosan per number of $\mathrm{Pb}$ (II) ions sorbed was 115 and 29, respectively.

\section{MATERIALS AND METHOD}

Samples of desized, scoured and bleached cotton fabric having a plain-weave structure with 25 ends $\times 21$ picks per centimeter and $122.2 \mathrm{~g} / \mathrm{m}^{2}$ weight, were scoured with non-ionic scouring and wetting agent (Sandozin NIE, generally $1 \mathrm{~g} / \mathrm{l}$, liquor ration $1 \mathrm{~g}: 50 \mathrm{ml}$ ) at $60^{\circ} \mathrm{C}-70^{\circ} \mathrm{C}$ for 30 minutes. The samples were then rinsed in warm water and then three times in cold water and drip-dried. 
A part of cotton sample was treated with chitosan-acetic acid solution, with concentration of chitosan $4 \%(\mathrm{w} / \mathrm{V})$ and acetic acid $2 \%(\mathrm{w} / \mathrm{v})$, and the samples named $\mathrm{C}_{4} \mathrm{~A}_{2}$. Another cotton samples were then treated with chitosan-polycarboxylic acids mixtures. For chitosan-citric acid solution, the concentration used was chitosan $4 \%(w / v)$, citric acid $6 \% \quad(\mathrm{w} / \mathrm{v})$ and sodium hypophosphite $6 \%(w / v)$, the sample was named $\mathrm{C}_{4} \mathrm{C}_{6} \mathrm{P}$. For chitosan-maleic solution, the concentration used was chitosan $4 \%$ $(\mathrm{w} / \mathrm{v})$, maleic acid $6 \%(\mathrm{w} / \mathrm{v})$ and sodium hypophosphite $6 \%(\mathrm{w} / \mathrm{v})$, the sample was named $\mathrm{C}_{4} \mathrm{M}_{6} \mathrm{P}$.

In preparing chitosan complexes with metal ions, the untreated and treated cotton samples $(\sim 0.8 \mathrm{~g})$ were treated separately with $80 \mathrm{ml}$ of $0.25 \mathrm{M}$ copper sulphate $\left(\mathrm{CuSO}_{4}\right)$ solution and $0.15 \mathrm{M}$ zinc sulphate $\left(\mathrm{ZnSO}_{4}\right)$ solution. The fabric both untreated and treated, size $10 \times 5 \mathrm{~cm}$, were weighed, and the placed in steel dyeing tubes with the solutions and rotated at room temperature for 1 hour. After that, the salt solutions were poured off and the fabrics were washed with distilled water and allowed to dry overnight at room temperature. These samples are used to measure the water repellent effect of the treated fabrics.

To measure the quantity of metal ion absorbed by the fabric, the fabric $(\sim 0.8 \mathrm{~g})$ was treated in $30 \mathrm{ml}$ of $0.15 \mathrm{M}$ copper (II) sulphate at room temperature for $1 \mathrm{~h}$. After that the salt solution was poured off and the fabrics were washed with distilled water and allowed to dry overnight at room temperature. The salt solution concentration before and after the chelation process was determined on a CECIL spectrophotometer at $810 \mathrm{~nm}$. Another fabrics $(\sim 0.8 \mathrm{~g})$ was treated in $30 \mathrm{ml}$ of $0.15 \mathrm{M}$ copper (II) acetate at temperature $70^{\circ}-80^{\circ} \mathrm{C}$, then follow the process as copper (II) sulphate.

\section{RESULTS AND DISCUSION}

Towards the end of the present study, it was realized that the chitosan treated cotton samples should be able to absorb metal ions, particularly copper and zinc salts. ${ }^{17,23,26,27)}$ Some experiments were carried out, and as will be seen, led to some very unexpected results. The data on the absorption of copper salts from solution are presented, although several anomalies were noted and no time was available to check the procedures.

Several treated fabrics (samples $\mathrm{C}_{4} \mathrm{~A}_{2}$, $\mathrm{C}_{4} \mathrm{C}_{6} \mathrm{P}$ and $\mathrm{C}_{4} \mathrm{M}_{6} \mathrm{P}$ after curing) were treated with $0.15 \mathrm{M}$ salt solutions (copper sulphate and copper acetate) at $70^{\circ} \mathrm{C}-80^{\circ} \mathrm{C}$ for $1 \mathrm{~h}$ on the wash wheel. The fabrics were then washed with distilled water and allowed to dry at room temperature over-night. This procedure was also applied to those samples after washing (washed with the solution of Sandozin $\operatorname{NIE}(1 \%, w / v)$ at $60^{\circ} \mathrm{C}$ for 30 minutes).

To examine further the quality of copper absorbed on the fabrics, samples $\mathrm{C}_{4} \mathrm{~A}_{2}$ and $\mathrm{C}_{4} \mathrm{C}_{6} \mathrm{P}$ were cut into $10 \times 5 \mathrm{~cm}^{2}$ samples which weighed about 0.7 to $0.8 \mathrm{~g}$. The samples were then dyed with $0.15 \mathrm{M}$ copper (II) sulphate solution at room temperature and also at $70-80^{\circ} \mathrm{C}$ for $1 \mathrm{~h}$ in each case. Several samples were also dyed with $0.075 \mathrm{M}$ copper (II) acetate at $70-80^{\circ} \mathrm{C}$ for $1 \mathrm{~h}$ (the copper acetate was used at twice the dilution of the $\mathrm{CuSO}_{4}$ due to its stronger colour). Before testing, the absorbance of five different concentrations of both salts were measured to establish calibration plots. The calibration plots for copper sulphate and copper acetate are shown in Figure 2 and 3 respectively.

The equations of the lines were found by linier regression, as follows:

For copper (II) sulphate solution, (from Figure 2.)

$$
\begin{aligned}
Y=A+B X \rightarrow A & =0.01055 \\
B & =0.04708\left(\mathrm{I} \mathrm{g}^{-1}\right)
\end{aligned}
$$




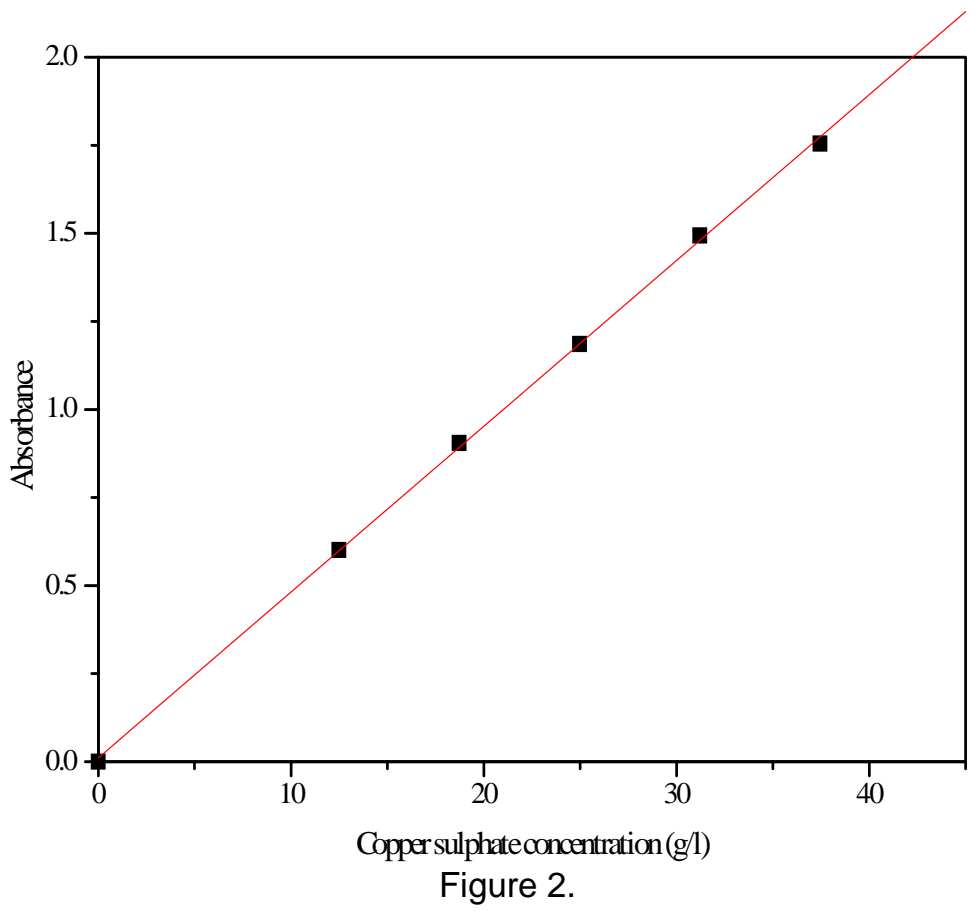

The UV absorbance of copper (II) sulphate solution

For copper (II) acetate solution, (from figure 3.)

$$
\begin{array}{r}
Y=A+B X \quad \rightarrow A=-0.01368 \\
B=0.1215\left(\mathrm{I} \mathrm{g}^{-1}\right)
\end{array}
$$

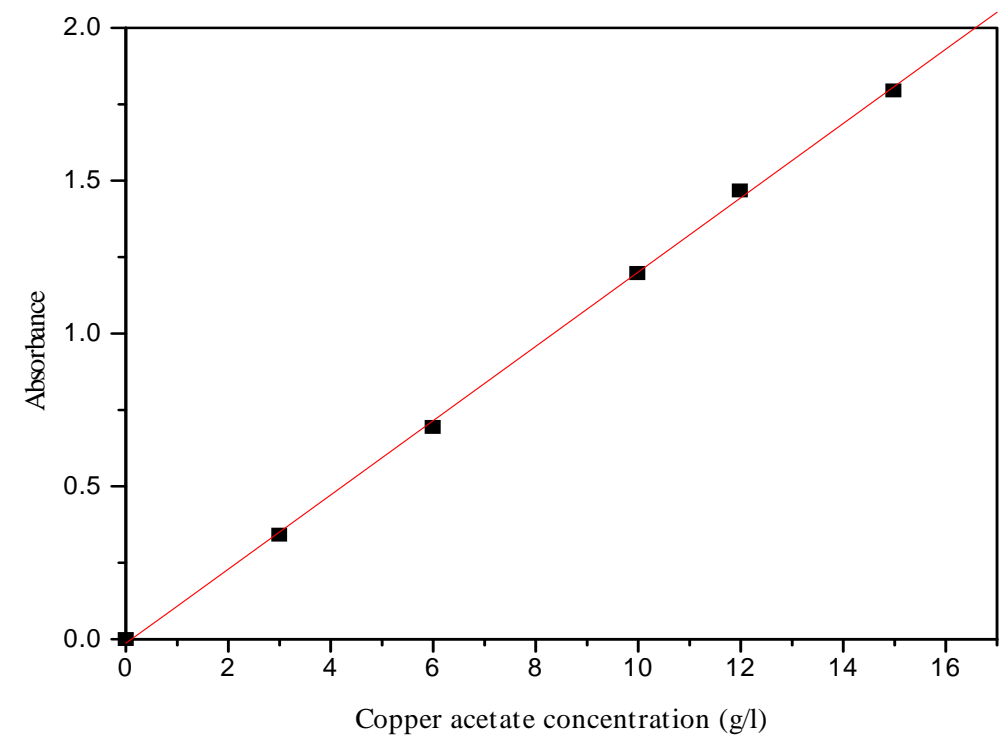

Figure 3.

The UV absorbance of copper (II) acetate solution at $810 \mathrm{~nm}$

Absorbance measurements were made before and after dyeing, as shown in Table 1. The amounts of copper ions absorbed by the sample $\mathrm{C}_{4} \mathrm{C}_{6} \mathrm{P}$ were higher than that absorbed by sample $\mathrm{C}_{4} \mathrm{~A}_{2}$ except at the lowest concentration used. What was confusing was the variation of copper sulphate absorbed with solution concentration which did not seem logical.
The absorption of copper by fabrics was increased at higher temperature. At a dyeing temperature of $70^{\circ} \mathrm{C}-80^{\circ} \mathrm{C}$ for $1 \mathrm{~h}$, the results obtained are shown in Table 2. At the highest concentrations, more copper was absorbed by the fabrics at the higher temperature and again sample $\mathrm{C}_{4} \mathrm{C}_{6} \mathrm{P}$ absorbed more copper than the comparable sample $\mathrm{C}_{4} \mathrm{~A}_{2}$. The variation of absorption of 
copper sulphate with concentration was again very odd particularly with one solution where apparently no copper was absorbed, despite a blue colour in the fabric.

Table 1.

The UV absorbance of copper sulphate solution before and after dyeing the treated fabrics (dyed at $70^{\circ} \mathrm{C}-80^{\circ} \mathrm{C}$ for $1 \mathrm{~h}$ )

\begin{tabular}{lcccccc}
\hline Sample & $\begin{array}{c}\text { Weight } \\
(\%)\end{array}$ & \multicolumn{2}{c}{ Salt solution (ml) } & \multicolumn{2}{c}{ Absorbance } & \begin{tabular}{c} 
Copper content \\
on dyed fabric \\
\cline { 3 - 6 }
\end{tabular} \\
\cline { 3 - 6 } & $\begin{array}{c}\mathrm{CuSO}_{4} \\
(0.15 \mathrm{M})\end{array}$ & Water & $\begin{array}{c}\text { Before } \\
\text { dyeing }\end{array}$ & $\begin{array}{c}\text { After } \\
\text { dyeing }\end{array}$ & $(\%)$ \\
\hline $\mathrm{C}_{4} \mathrm{~A}_{2}$ & 0.7513 & 30 & 0 & 1.729 & 1.694 & 2.97 \\
$\mathrm{C}_{4} \mathrm{~A}_{2}$ & 0.7557 & 15 & 15 & 0.921 & 0.861 & 5.06 \\
$\mathrm{C}_{4} \mathrm{~A}_{2}$ & 0.7540 & 5 & 25 & 0.288 & 0.288 & 0 \\
& & & & & & \\
$\mathrm{C}_{4} \mathrm{C}_{2} \mathrm{P}$ & 0.8236 & 30 & 0 & 1.729 & 1.646 & 6.43 \\
$\mathrm{C}_{4} \mathrm{C}_{2} \mathrm{P}$ & 0.8212 & 15 & 15 & 0.921 & 0.822 & 7.69 \\
$\mathrm{C}_{4} \mathrm{C}_{2} \mathrm{P}$ & 0.8201 & 5 & 25 & 0.288 & 0.272 & 1.24 \\
\hline
\end{tabular}

The possibility that the citric acid treated samples would contain free carboxylic groups led to the use of copper acetate instead of copper sulphate. Acetate should be able to exchange with carboxyl groups in the cotton to form carboxylate groups, which should increase the metal ion absorption. ${ }^{18)}$
As shown in Table 2, both sets of samples were dyed with copper acetate $(0.075 \mathrm{M})$ at $70^{\circ}-80^{\circ} \mathrm{C}$ for $1 \mathrm{~h}$. The lower absorbances of solutions after the dyeing of samples $\mathrm{C}_{4} \mathrm{C}_{6} \mathrm{P}$ compared to samples $\mathrm{C}_{4} \mathrm{~A}_{2}$ indicated that the samples $\mathrm{C}_{4} \mathrm{C}_{6} \mathrm{P}$ (treated with chitosan-citric acid solution) were able to absorb more of the copper acetate.

Table 2.

The UV absorbance of copper acetate solution before and after dyeing the treated fabrics (dyed at $70^{\circ} \mathrm{C}-80^{\circ} \mathrm{C}$ for $1 \mathrm{~h}$ )

\begin{tabular}{lcccccc}
\hline & Weight & \multicolumn{2}{c}{ Salt solution $(\mathrm{ml})$} & \multicolumn{2}{c}{ Absorbance } & Copper content \\
\hline Sample & $(\%)$ & $\begin{array}{c}\text { Cu-acetate } \\
(0.075 \mathrm{M})\end{array}$ & Water & $\begin{array}{c}\text { Before } \\
\text { dyeing }\end{array}$ & $\begin{array}{c}\text { After } \\
\text { dyeing }\end{array}$ & $\begin{array}{c}\text { on dyed fabric } \\
(\%)\end{array}$ \\
\hline $\mathrm{C}_{4} \mathrm{~A}_{2}$ & 0.7531 & 30 & 0 & 1.830 & 1.619 & 6.92 \\
$\mathrm{C}_{4} \mathrm{~A}_{2}$ & 0.7560 & 15 & 15 & 0.884 & 0.760 & 4.05 \\
$\mathrm{C}_{4} \mathrm{~A}_{2}$ & 0.7508 & 5 & 25 & 0.264 & 0.223 & 1.35 \\
& & & & & & \\
$\mathrm{C}_{4} \mathrm{C}_{6} \mathrm{P}$ & 0.8223 & 30 & 0 & 1.830 & 1.475 & 10.67 \\
$\mathrm{C}_{4} \mathrm{C}_{6} \mathrm{P}$ & 0.8247 & 15 & 15 & 0.884 & 0.631 & 7.58 \\
$\mathrm{C}_{4} \mathrm{C}_{6} \mathrm{P}$ & 0.8198 & 5 & 25 & 0.264 & 0.109 & 4.67 \\
\hline
\end{tabular}

By using equation (1), the concentration of copper acetate, before and after dyeing, was calculated and the copper acetate absorbed by the fabrics is given in Table 2 . It seems likely that sample $\mathrm{C}_{4} \mathrm{C}_{6} \mathrm{P}$, with a higher free carboxyl group content does have a higher absorbance of metal ions. In this case, the amount of copper absorbed does increase with the increase in the concentration of copper ions used, in marked contrast to the copper sulphate results.

At this stage, a most unexpected result was obtained. All the dyed samples showed a remarkable water repellency effect, when 
they were subjected to the water droplet test. Surprisingly, the water repellency power was in the order of sample $\mathrm{C}_{4} \mathrm{C}_{6} \mathrm{P}>$ sample $\mathrm{C}_{4} \mathrm{M}_{6} \mathrm{P}>$ sample $\mathrm{C}_{4} \mathrm{~A}_{2}$. It must be emphasized that all samples treated with chitosan-acetic acid alone or with chitosanpolycarboxylic acid alone showed no water repellency effect. The effect only became apparent after treatment with the metal salt solutions. But the water repellency effect on cotton treated with chitosan-acetic acid was shorter lived than samples treated with chitosan-polycarboxylic acids. The water repellency effect also appeared on samples $\mathrm{C}_{4} \mathrm{~A}_{2}, \mathrm{C}_{4} \mathrm{C}_{6} \mathrm{P}$ and $\mathrm{C}_{4} \mathrm{M}_{6} \mathrm{P}$ which were dyed after washing, but the effect on these samples was not as strong as the water repellency of samples which were dyed after curing the samples.

The investigation was also extended to the effect of metal ions on the untreated cotton and the cotton treated with citric acid alone (sample $\mathrm{C}_{6} \mathrm{P}$ ). Both samples were treated with both the above solutions, and then were subjected to the water droplet test. Although both samples were dyed with copper sulphate (confirmed by the blue colour of the samples), both samples showed no water repellency (similarly, the zinc sulphate treated fabrics gave no water repellency). It is clear that chitosan in combination with a polycarboxylic acid can give an increase in the water repellency of the fabrics. This result was very surprising but was thought to be related to the presence of the waxy impurities in the chitosan. When chitosan treated cotton fabric was dyed with copper sulphate, chitosan complexes with the copper. Perhaps, as a result of this the waxy component is able to move to the surface of the fabric, and as a result the fabrics now show water repellency. To confirm this theory, the dyed samples were subjected to treatment with acid, alkali, detergent, and solvents as described below.

Several samples which showed water repellency were treated with $0.1 \mathrm{M}$ aqueous hydrochloric acid, $0.1 \mathrm{M}$ aqueous sodium hydroxide, $0.1 \mathrm{M}$ aqueous EDTA and $0.2 \%$ (w/v) Sandozin NIE (nonionic detergent). Samples $\mathrm{C}_{4} \mathrm{~A}_{2}-\mathrm{Cu}, \mathrm{C}_{4} \mathrm{C}_{6} \mathrm{P}-\mathrm{Cu}$ (consisting of samples $\mathrm{C} 4 \mathrm{C} 6 \mathrm{P}$ dyed with copper sulphate denoted as $\mathrm{C}_{4} \mathrm{C}_{6} \mathrm{P}-\mathrm{Cu}(1)$ and $\mathrm{C}_{4} \mathrm{C}_{6} \mathrm{P}$ from a washed sample treated with copper acetate at $70^{\circ}-80^{\circ} \mathrm{C}$ denoted as $\left.\mathrm{C}_{4} \mathrm{C}_{6} \mathrm{P}-\mathrm{Cu}(2)\right)$ were cut into $2.5 \times 2.5 \mathrm{~cm}$ squares and treated separately in $10 \mathrm{ml}$ aqueous solutions at room temperature for 30 minutes with stirring. Treatment with Sandozin NIE, was carried out at $50-60^{\circ} \mathrm{C}$. The results are tabulated in Table 3.

Table 3.

The water droplet test of dyed fabrics

after treatment with solvent and several aqueous solution

\begin{tabular}{cccccc}
\hline Sample & $\mathrm{HCl}$ & $\mathrm{NaOH}$ & $\mathrm{EDTA}$ & Sandozin NIE & $\mathrm{CH}_{2} \mathrm{Cl}_{2}$ \\
\hline $\mathrm{C}_{4} \mathrm{C}_{6} \mathrm{P}-\mathrm{Cu}(1)$ & $\mathrm{vvv}$ & $\mathrm{x}$ & $\mathrm{vvv}$ & $\mathrm{x}$ & $\mathrm{vvv}$ \\
$\mathrm{C}_{4} \mathrm{~A}_{2}$ & $\mathrm{v}$ & $\mathrm{vv}$ & $\mathrm{v}$ & $\mathrm{x}$ & $\mathrm{vv}$ \\
$\mathrm{C}_{4} \mathrm{C}_{6} \mathrm{P}-\mathrm{Cu}(2)$ & $\mathrm{v}$ & $\mathrm{x}$ & $\mathrm{v}$ & $\mathrm{v}$ & $\mathrm{vvv}$ \\
\hline
\end{tabular}

Note : (x) water spread quickly, (v) slow down spreading, (vv) water repellency (vvv) strong water repellency (more than 15 minutes)

After $\mathrm{NaOH}$ and Sandozin NIE treatments, dyed fabrics remained blue but the water repellency disappeared (except for sample $\mathrm{C}_{4} \mathrm{~A}_{2}$ which showed a slight water repellency). It was concluded that the water repellency was mainly due to oleic acid (which had been shown to be the main waxy impurity) $^{27)}$ which was removed by alkali as the salt. On the other hand, after treatment with $\mathrm{HCl}$ and EDTA, the colour of dyed fabrics had disappeared but the fabrics still showed water repellency particularly sample $\mathrm{C}_{4} \mathrm{C}_{6} \mathrm{P}-\mathrm{Cu}(1)$. It can be concluded that the copper in the dyed fabrics was removed by acid and by the EDTA but the waxy compound was still present on the fabric and thus gave the water repellency effect. However, in the dyed fabrics extracted with dichloromethane, the fabric still showed water repellency. This suggested that the waxy material was not easily removed by the solvent, which was not expected.

\section{CONCLUSION}

Few researchers ${ }^{28)}$ claimed that there was evidence of a reaction between chitosan and cellulose which gave a product which remained undissolved in cuprammonium hydroxide solution. The present study showed that if there is a crosslinking reaction little insoluble product results after treating 
the treated fabric successively with cuprammonium hydroxide, acetic acid and again with cuprammonium hydroxide. There was evidence for reaction of the polycarboxylic acids with the cotton from the improved crease recovery angles observed but again extractions with cuprammonium hydroxide and acetic acid gave only small residues. It may be that where ester groups formed by reaction of polycarboxylic acid groups with the hydroxyl groups of the cotton or the chitosan, these hydrolysed during the cuprammonium hydroxide extraction. Investigations to determine how much crosslinking has occurred in these systems could be carried out using other solvents, less likely to hydrolyse ester groups (eg. DMA-LiCl).

By using polycarboxylic acid solutions of chitosan instead of acetic acid, it becomes possible to produce cotton which has both carboxyl and amine functional groups. The evidence for carboxyl groups at a level of about $0.5 \mathrm{meqs} / \mathrm{g}$ was found for both citric and maleic acid-chitosan combinations. There are implications for dyeing cotton making use of these groups but this was not investigated. Instead, the complexing of the treated cotton samples with copper and zinc salts was examined. The copper salt solutions gave blue fabrics confirming easily that complexing or chelation had occurred. Attempts to make quantitative measurements gave rather confusing results as the concentration of the copper sulphate solution was varied. Most noticeable, however, as discussed earlier, was the water repellency of both copper and zinc salt treated fabrics. It was intended to look into the conversion of the carboxyl groups to zinc or calcium carboxylate groups to see if these would reduce the flammability of the samples but no time was available ; further studies on this aspect might be useful.

\section{ACKNOWLEDGEMENTS :}

This research has been prepared in the Laboratorium of Balai Besar Tekstil Bandung with some colleagues by self financing.

\section{REFERENCE}

1. Muzzarelli, R.A.A., Natural Chelating Polymer, Pergamon Press, New York, 1973

2. Shanmugapriya, A., Ramya,R., Ramasubramaniam,S., and Sudha,P.N., Studies on removal of $\mathrm{Cr}(\mathrm{VI})$ and $\mathrm{Cu}$ (II) ions using chitosan grafted- polyacrylonitrile, Applied Science Research, 3 (3), 2011, p424-435.

3. Bamgbose,J.T., Adewuyi,S., Bamgbose,O., and Adetoye,A.A., Adsorption kinetics of cadmium and lead by chitosan, African Journal of Biotechnology, Vol.9(17), 2010, p25602565.

4. Onsoyen, E. and Skangrud, O., J. Chem. Tech. Biotechnology, 49 (1990), 395.

5. Lasko, C.L., Pesic, B.M. and Oliver, D.J., J. Appl. Polym. Sci., 48, (1993), 1965.

6. Hadi,A.G., Study of heavy metal Mn2+ adsorption by sythesized chitosan, British Journal of Science, Vo.6(2), 2012, p127-130.

7. Shanmugapriya,A., Hemalatha,M., Scholastica, B. and Augustine Arul Prasad,T., Adsorption studies of Lead (II) and nickel (II) ions on chitosan-Gpolyacrylonitrile, Der Pharma Chemica, 5(3), 2013, p141-155.

8. Muhaemin, M., Chelating ability of crab shell particles and extracted acetamido groups (chitin and chitosan) from Portunus $s p$ to lead $\left(\mathrm{Pb}^{2+}\right)$, Journal of Coastal Development, Vol 9, No. 1, Oct 2005, p1-7.

9. Shin Juang, R., Chin Wu, F., and Ling Tseng, R., Adsorption removal of copper (II) using chitosan from simulated rinse solutions containing chelating agents, Water Research, Vol 33, Issue 10, Jul 1999, p2403-2409

10. Laksono, E.W., Prodjosantoso, A.K. and Ikhsan, J., A complex surface formation model on chitosan adsorption to metals, FMIPA (Pendidikan Kimia), 2006.

11. Jiang, W., Tao, T., Liao, Z., Removal of heavy metal from contaminated soil with chelating agents, Open Journal of Soil Science, 1, 2011, p70-76.

12. Schlick, S., Macromolecules, 19 (1986), 192.

13. Domard, A., Int. J. Biol. Macromol., 9, 1987, 333

14. Muzzarelli, R.A.A. and Turbetini, O., Microchem. Acta, 5 (1970), 892.

15. Koshijima, T., Tanak, R., Muraki, E., Yamada, A. And Yaku, F., Cellulose Chem. Technol., 7, 1973, 197.

16. Hussein, M.H.M., El-Hady, M.F., Sayed, W.M., Hefni, H., Preparation of some chitosan heavy metal complexes and study of its properties, Polymer Science, Ser.A, Vol. 54, No.2, 2012, p113-124.

17. Roberts, G.A.F., Chitin Chemistry, Macmillan, London, 1992.

18. Uraki, Y. and Tokura, S., J. Macromol. Sci. Chem., A25 (1988), 1427. 
19. Muzzarelli, R.A.A. Tamfani, F., Emanuelli, M. And Mariotti, A., Carbohydr. Res., 107, 1982, 199-214.

20. Nud'ga, L.A., Plisko, E.A. and Danilov, S.N., Zh. Obshsh. Khim., 43, 1973, 2752; Hirano, S., Matsuda, N., Miura, O. And Iwaki, H., Carbohydr. Res., 71, 1979, 339.

21. Hall, L.D. and Yalpani, M., Carbohydr. Res. 83, 1980, C5-C7.

22. Hovey, R.J., O' Connell, J.J. and Martell, A.E., J.Am. Chem. Soc., 81 (1959), 3189.

23. Muzzarelli, R.A.A., Chitin, Pergamon: Oxford, 1977, Chapter 6.
24. Blair, H.S. and Ho, T.C., J. Chem. Tech. Biotechnol., 31 (1980), 6.

25. Eiden, C.A., Jewell, C.A. and Wightman, J.P., J. Appl. Polym. Science, 25, (1980), 1587

26. Qin, Y., PhD Thesis, Department of Textile Industries, The University of Leeds, 1990

27. Habibie, S., PhD Thesis, Department of Textile Industries, The University of Leeds, 1996.

28. Lu, F., PhD Thesis, Department of Textile Industries, The University of Leeds, April 1992. 